\title{
Studi komparatif kinerja keuangan daerah Kota Jambi dan Provinsi Jambi
}

\author{
Faradilla Herlin*1; M. Syurya Hidayat $^{2}$ \\ ${ }^{1}$ Fakultas Ekonomi Bisnis Universitas Muhammadiyah Jambi \\ ${ }^{2}$ Fakultas Ekonomi Bisnis Universitas Universitas Jambi \\ *E-mail korespodensi: faradilla.surya@gmail.com
}

\begin{abstract}
The analysis carried out aims to perform a comparative analysis of the regional financial performance of Jambi City and Jambi Province. The analytical method used is the secondary data comparative analysis method. The analytical model used is an indicator of fiscal dependence, income generation capacity, an indicator of the proportion of capital expenditures, and an indicator of the contribution of the government sector. The analysis results conclude that overall, the regional financial performance of Jambi City is better than Jambi Province.
\end{abstract}

Keywords : Fiscal dependence, Income generation capacity, The proportion of capital expenditures, Contribution of the government sector

\begin{abstract}
Abstrak
Analisis yang dilakukan bertujuan untuk melakukan analisis komparatif terhadap kinerja keuangan daerah Kota Jambi dan Provinsi Jambi. Metode analisis yang digunakan adalah metode analisis komparatif data sekunder. Model analisis yang digunakan adalah indikator ketergantungan fiskal, indikator kapasitas pembangkitan pendapatan, indikator proporsi belanja modal dan indikator kontribusi sektor pemerintah. Hasil analisis menyimpulkan bahwa secara keseluruhan kinerja keuangan daerah Kota Jambi lebih baik dari Provinsi Jambi
\end{abstract}

Kata kunci: Ketergantungan fiskal, Kapasitas menghasilkan pendapatan, Proporsi belanja modal, Kontribusi sektor pemerintah

\section{PENDAHULUAN}

Dilihat dari sisi anggaran, pemerintah daerah menggunakan anggaran sebagai instrumen kebijakan dalam menentukan arah dan tujuan pembangunan daerah. Hal ini terlihat dari perumusan kebijakan di dalam anggaran yang dibagi berdasarkan proporsi sektor ekonomi. Arah kebijakan pembangunan pemerintah daerah akan terlihat pada sector ekonomi yang memiliki proporsi terbesar dalam anggaran (Bacarreza,dkk.2019). Ini berarti, ketersediaan anggaran menjadi hal yang sangat urgen dalam pencapaian tujuan pembangunan daerah. Untuk itu, pemerintah daerah harus memiliki strategi tersendiri dalam meningkatkan kemampuan keuangan daerahnya.

Upaya peningkatan kemampuan keuangan daerah diakui bukanlah suatu hal yang mudah secara operasional. Terbatasnya infrastruktur, rendahnya kesadaran masyarakat dan lemahnya piranti hukum dan peraturan, serta keterampilan dan profesionalisme petugas yang masih timpang, merupakan beberapa hal yang menjadi kendala peningkatan kemampuan dan kinerja keuangan daerah (Blochliger,2018). Kendala yang dihadapi relatif bertambah seiring dengan terjadinya perubahan dalam sistim pengelolaan keuangan daerah. Hal ini sejalan dengan dikeluarkannya Undang-undang Nomor 17 Tahun 2003, Undang-undang Nomor 22 Tahun 2003, Undang-undang Nomor 1 Tahun 
2005 dan Undang-undang 32 tahun 2005 yang berimplikasi pada pelaksanaan penyelenggaraan pemerintahan dan sistem pengelolaan keuangan negara dan daerah.

Dengan perubahan sistem, secara langsung juga berpengaruh terhadap pengelolaan keuangan di daerah. Pendekatan yang selama ini menggunakan pendekatan proyek, selaras dengan paradigma baru dirubah dengan menggunakan pendekatan sistem Anggaran Berbasis Kinerja(ABK). Perubahan-perubahan yang terjadi tersebut membawa konsekuensi pada kinerja keuangan daerah, termasuk kinerja keuangan daerah yang akan sangat tergantung dari pendapatan yang diperoleh oleh daerah itu sendiri, baik yang berasal dari pemerintah pusat, pemerintah provinsi maupun atas upaya penggalian pendapatan asli daerah itu sendiri.

Kinerja keuangan daerah merupakan suatu hal yang sangat penting dikarenakan terkait secara langsung dengan pencapaian tujuan pembangunan (Bartolini,2016). Semakin baik kinerja keuangan suatu daerah maka akan semakin berdampak positif terhadap kesejahteraan masyarakat. Ada empat indicator yang dapat mencerminkan kinerja keuangan suatu daerah yaitu indicator ketergantungan fiscal, indicator kapasitas penciptaan pendapatan, indicator proporsi belanja modal dan indicator kontribusi sector pemerintah.

Dikarenakan begitu pentingnya informasi mengenai kinerja keuangan suatu daerah maka perlu dilakukan analisis yang lebih mendalam. Dalam tulisan ini akan dilakukan analisis komparasi antara kinerja keuangan Kota Jambi dengan kinerja keuangan Provinsi Jambi. Analisis komparasi dilakukan dikarenakan Kota Jambi merupakan salah satu daerah di Provinsi Jambi yang memperlihatkan kinerja keuangan yag lebih baik dibandingkan daerah lainnya. Sedangkan komparasi dilakukan terhadap Provinsi Jambi, dengan alasan sebagai daerah induk, yang lebih mencerminkan kinerja keuangan seluruh daerah di Provinsi Jambi.

\section{METODE}

Dalam penelitian ini akan digunakan metode analisis studi komparatif data sekunder. Yang dimaksud dengan analisis studi komparatif data sekunder adalah analisis perbandingan data antar dua objek yang dianalisis, dalam hal ini adalah kinerja keuangan Kota Jambi dengn kinerja keuangan Provinsi Jambi. Analisis data yang dilakukan dalam tulisan ini mengenai Kinerja keuangan daerah. Ada empat model analisis indicator kinerja keuangan daerah yang digunakan. Adapun empat model yang dimaksud adalah berikut ini:

\section{Indikator ketergantungan fiskal (FID)}

$$
\text { FID }=100 \text { - } \frac{(\mathrm{DAU}-\mathrm{BP})}{\mathrm{TPD}}
$$

\section{Dimana:}

FID = Tingkat ketergantungan fiskal

DAU $=$ Dana alokasi umum

$\mathrm{BP} \quad=$ Belanja pegawai

$\mathrm{TPD}=$ Total pendapatan daerah

\section{Kapasitas penciptaan pendapatan (FGI)}

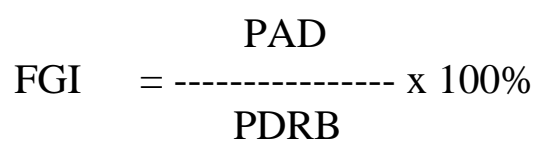


Dimana :

FGI = Kapasitas penciptaan pendapatan

PAD = Pendapatan asli daerah

PDRB $=$ Produk domestik regional bruto

\section{Proporsi belanja modal (FCAPEX)}

$\mathrm{BM}$

FCAPEX =------------ x 100\%

TBD

Dimana :

FCAPEX $=$ Proporsi belanja modal

$\mathrm{BM}=$ Belanja modal

TBD $=$ Total Belanja Daerah

Kontribusi sektor pemerintah (FCE)

TBD

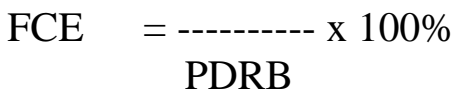

Dimana :

FCE $=$ Kontribusi sektor pemerintah

TBD = Total belanja daerah

PDRB = Produk Domestik Regional Bruto

Berdasarkan empat rumus diatas maka dapat dilakukan perhitungan Indeks Kinerja Keuangan Daerah (IKKD) sebagai berikut (Bappenas-UNDP, 2007) :

IKKD $_{i, 1}$

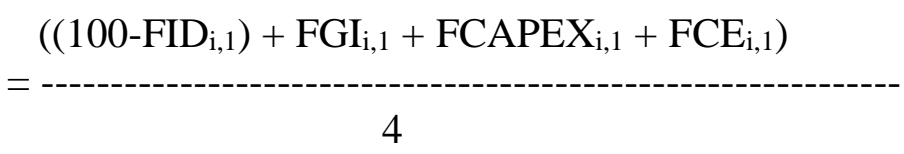

\section{HASIL DAN PEMBAHASAN}

Secara substansi, ketergantungan fiscal adalah perbandingan antara Dana Alokasi Umum (yang sudah dikurangi oleh Belanja Pegawai) dengan Total Pendapatan didalam anggaran daerah bersangkutan, dihitung dalam satuan persen per tahun. Ini berarti, semakin kecil nilai yang dihasilkan maka mencerminkan semakin rendah tingkat ketergantungan dari daerah dimaksud.

Berdasarkan perhitungan yang dilakukan maka diketahui bahwa tingkat ketergantungan fiscal Kota Jambi jauh lebih rendah dibandingkan Provinsi Jambi. Ini berarti, Provinsi Jambi memiliki ketergantungan anggaran terhadap pemerintah pusat lebih besar didalam pendanaan APBD nya. Ini juga mencerminkan cukup besarnya kemampuan Kota Jambi dalam pembiayaan pembangunan. Namun demikian, setelah tahun 2017 tingkat ketergantungan fiscal Kota Jambi cukup besar.

Rendahnya nilai ketergantungan fiscal juga mencerminkan kemampuan pemerintah Kota Jambi dalam meningkatkan pendapatan daerahnya, terutama yang bersumber dari Pendapatan Asli Daerah. Inilah yang sebenarnya makna dari otonomi daerah, yaitu kemampuan daerah dalam mengelola anggarannya dalam merealisasikan rencana pembangunannya. Informasi lebih lengkap dapat dilihat pada table berikut : 
Tabel 1. Perkembangan tingkat ketergantungan fiskal Kota Jambi dan Provinsi Jambi, Tahun 2015-2019.

\begin{tabular}{lrcccc}
\hline \multirow{1}{*}{ Wilayah } & \multicolumn{5}{c}{ Tingkat ketergantungan fiskal } \\
\cline { 2 - 6 } & $\mathbf{2 0 1 5}$ & $\mathbf{2 0 1 6}$ & $\mathbf{2 0 1 7}$ & $\mathbf{2 0 1 8}$ & $\mathbf{2 0 1 9}$ \\
\hline Kota Jambi & $1.11 \%$ & $0.37 \%$ & $7.04 \%$ & $26.96 \%$ & $58.97 \%$ \\
Provinsi Jambi & $12.94 \%$ & $22.48 \%$ & $6.27 \%$ & $18.60 \%$ & $32.33 \%$
\end{tabular}

Sumber : Data diolah, 2020

Kinerja keuangan daerah berikutnya dapat dilihat dari Kapasitas Penciptaan Pendapatan. Adapun yang dimaksud dengan Kapasitas Penciptaan Pendapatan adalah Proporsi PAD terhadap nilai PDRB daerah bersangkutan, dihitung dalam satuan persen per tahun. Rasio ini menunjukan bahwa semakin tinggi nilainya berarti semakin besar kemampuan PAD dalam menghasilakn pendapatan daerah, yang tercermin pada nilai PDRB.

Berdasarkan hasil perhitungan maka diketahui bahwa nilai Kapasitas Penciptaan Pendapatan Kota Jambi lebih besar dibandingkan Provinsi Jambi. Ini berarti, kemampuan Pemerintah Kota Jambi dalam menghasilkan PAD mampu berdampak positif terhadap perekonomian daerah. Lebih lanjut, hal ini juga mencerminkan bahwa PAD yang diperoleh oleh Pemerintah Kota Jambi yang digunakan untuk membiayai proyek pembangunan, digunakan secara tepat dan memiliki dampak terhadap perekonomian daerah (G.Chirwa and Odhiambo,2016). Hal sebaliknya terjadi untuk Provinsi Jambi, dimana nilai Kapasitas Penciptaan Pendapatannya rata rata dibahwa satu.

Hasil perhitungan Kapasitas Penciptaan Pendapatan menjadi sangat menarik untuk dikomparasikan. Bukan hanya mencerminkan kemampuan Kota Jambi dalam menghasilkan PAD namun juga mencerminkan kemampuan dalam membuat perencanaan pembangunan dan merealisasikannya. Sehingga peningkatan penerimaan PAD yang digunakan kembali untuk membiayai proyek pembangunan, berdampak positif. Perbandingan nilai Kapasitas Penciptaan Pendapatan antara Kota Jambi dengan Provinsi Jambi dapat dilihat pada table berikut :

Tabel 2. Perkembangan kapasitas penciptaan pendapatan Kota Jambi dan Provinsi Jambi, Tahun 2015-2019.

\begin{tabular}{lccccc}
\hline \multirow{2}{*}{ Wilayah } & \multicolumn{5}{c}{ Kapasitas penciptaan pendapatan (\%) } \\
\cline { 2 - 6 } & $\mathbf{2 0 1 5}$ & $\mathbf{2 0 1 6}$ & $\mathbf{2 0 1 7}$ & $\mathbf{2 0 1 8}$ & $\mathbf{2 0 1 9}$ \\
\hline Kota Jambi & 3.179 & 3.286 & 4.300 & 1.669 & 1.843 \\
Provinsi Jambi & 0.993 & 0.945 & 1.158 & 0.529 & 0.479 \\
\hline
\end{tabular}

Sumber: Data diolah, 2020

Indikator kinerja keuangan daerah berikutnya adalah nilai proporsi belanja modal. Adapun yang dimaksud dengan proporsi belanja modal adalah Perbandingan antara jumlah belanja modal terhadap total belanja daerah kabupaten kota bersangkutan, dihitung dalam satuan persen per tahun. Indikator ini cukup penting dikarenakan mencerminkan komitmen pemerintah dalam mengelola keuangannya (Ganaie N.A.Khan,2018). Idealnya, substansi utama dari kepercayaan yang diberikan masyarakat kepada suatu pemerintahan adalah adanya komitmen pemerintah untuk menggunakan anggaran sebesar besarnya untuk kesejahteraan rakyat. Hal ini didalam APBD tercermin dari besaran proporsi belanja modal terhadap total belanja.

Berdasarkan hasil perhitungan terhadap proporsi belanja modal maka terlihat proporsi yang cukup besar dialokasikan oleh pemerintah Kota Jambi untuk belanja modal. Tidak demikian halnya dengan Provinsi Jambi yang terus mengalami penurunan proporsi. 
Informasi komparatif mengenai proporsi belanja modal antara Kota Jambi dengan Provinsi Jambi dapat dilihat pada table berikut:

Tabel 3. Perkembangan proporsi belanja modal Tahun 2015-2019.

\begin{tabular}{lllllr}
\hline \multirow{2}{*}{ Wilayah } & \multicolumn{5}{c}{ Proporsi belanja modal } \\
\cline { 2 - 6 } & $\mathbf{2 0 1 5}$ & $\mathbf{2 0 1 6}$ & $\mathbf{2 0 1 7}$ & $\mathbf{2 0 1 8}$ & $\mathbf{2 0 1 9}$ \\
\hline Kota Jambi & 26.992 & 27.785 & 28.024 & 27.803 & 14.384 \\
Provinsi Jambi & 23.104 & 28.701 & 21.671 & 7.831 & 3.194 \\
\hline Sumber: Data diolah 2020 & & & &
\end{tabular}

Sumber: Data diolah, 2020

Rasio kinerja keuangan daerah berikutnya yang dianalisis adalah kontribusi sector pemerintah. Rasio kontribusi sector pemerintah ini adalah kontribusi total belanja pemerintah di dalam nilai PDRB daerah yang bersangkutan, dihitung dalam satuan persen per tahun. Substansi dari rasio ini adalah ingin melihat peranan pemerintah, yang tercermin dari nilai belanja APBD nya, yang berdampak terhadap perekonomian daerah (tercermin pada nilai PDRB) (Kim,2019).

Hasil analisis menunjukan bahwa peranan belanja daerah yang berperan sebagai stimulus fiscal dalam perekonomian Kota Jambi cukup significant. Hal ini dapat dilihat dari nilai kontribusi pemerintah yang cukup besar bila dibandingkan dengan Provinsi Jambi. Hal ini juga mencerminkan bahwa pemerintah benar benar bereperan dalam ikut menggerak perekonomian daerah (Korompot and Warongan,2017). Tentu saja peranan tersebut lebih mengarah sebagai pemicu atau trigger dalam bentuk penyediaan fasiltas dan infratruktur yang menunjang pergerakan perekonomian daerah. Informasi lebih jelas mengenai perbandingan antara kontribusi sector pemerintah Kota Jambi dengan Provinsi Jambi, dapat dilihat pada tabel berikut ini.

Tabel 4. Perkembangan rasio kontribusi sektor pemerintah Kota Jambi dan Provinsi Jambi, Tahun 2015-2019.

Wilayah

\begin{tabular}{lrrrrr}
\hline \multirow{1}{*}{ Wilayah } & \multicolumn{5}{c}{ Kontribusi Sektor Pemerintah (\%) } \\
\cline { 2 - 6 } & $\mathbf{2 0 1 5}$ & $\mathbf{2 0 1 6}$ & $\mathbf{2 0 1 7}$ & $\mathbf{2 0 1 8}$ & $\mathbf{2 0 1 9}$ \\
\hline Kota Jambi & 17.185 & 17.447 & 16.195 & 6.454 & 5.400 \\
Provinsi Jambi & 2.740 & 2.524 & 3.028 & 0.853 & 0.900 \\
\hline
\end{tabular}

Sumber: Data diolah, 2020

Berdasarkan keempat indicator kinerja keuangan daerah yang telah dianalisis secara parsial pada bagian terdahulu maka pada bagian berikut akan dilakukan perhitungan secara akumulatif. Hasil perhitungan secara akumulatif memperlihatkan bahwa kinerja keuangan Kota Jambi lebih tinggi atau lebih baik dibandingkan dengan kinerja keuangan Provinsi Jambi. Pada tahun 2015, kinerja keuangan Kota Jambi adalah sebesar 31,67 sedangkan Provinis Jambi hanya sebesar 31, 67. Pada tahun 2017, rasio kinerja keuangan Kota Jambi meningkat mencapai 37,112 sedangkan kinerja keuangan Provinsi Jambi turun pada angka 31,448.

Tabel 5. Perkembangan indikator kinerja keuangan Kota Jambi dan Provinsi Jambi, Tahun 2015-2019.

\begin{tabular}{llllll}
\hline \multirow{2}{*}{ Wilayah } & \multicolumn{5}{c}{ Indikator keuangan daerah } \\
\cline { 2 - 6 } & $\mathbf{2 0 1 5}$ & $\mathbf{2 0 1 6}$ & $\mathbf{2 0 1 7}$ & $\mathbf{2 0 1 8}$ & $\mathbf{2 0 1 9}$ \\
\hline Kota Jambi & 36.836 & 37.128 & 37.112 & 33.914 & 30.259 \\
Provinsi Jambi & 31.677 & 32.986 & 31.448 & 27.257 & 26.062 \\
\hline
\end{tabular}

Sumber: Data diolah, 2020 
Penurunan rasio kinerja keuangan daerah terjadi pada tahun 2019. Walaupun mengalami penurunan, nyatanya rasio kinerja keuangan Kota Jambi tetap lebih tinggi dibandingkan Provinsi Jambi. Adapaun rasio kinerja keuangan Kota Jambi adalah sebesar 30,259 sedangkan Provinsi Jambi dengan nilai yang lebih kecil yaitu sebesar 26,062. Informasi lebih detail dapat dilihat pada Tabel 5.

\section{KESIMPULAN DAN SARAN}

\section{Kesimpulan}

Berdasarkan analisis yang telah dilakukan pada bagian terdahulu maka dapat disimpulkan beberapa hal sebagai beikut: 1).Tingkat ketergantungan fiscal Kota Jambi menunjukkan trend yang meningkat dibandingkan Provinsi Jambi. 2).Kapasitas Penciptaan Pendapatan Kota Jambi lebih besar dibandingkan kemampuan Provinsi Jambi. 3).Kemampuan belanja modal dalam menggerak perekonomian Kota Jambi lebih besar dibandingkan Provinsi jambi. 4).Kontribusi sector pemerintah melalui belanja dalam menggerakan perekonomian Kota Jambi lebih besar dibandingkan Provinsi Jambi, 5).Secara keseluruhan, kinerja keuangan daerah Kota Jambi lebih baik dibandingkan dengan Provinsi Jambi.

\section{Saran}

Berdasarkan analisis dan kesimpulan terdahulu maka dapat disaran hal sebagai berikut : 1).Perlu dilakukan optimalisasi penerimaan daerah, khususnya PAD dalam rangka mengurangi ketergantungan pemeritah Kota Jambi dan khususnya lagi bagi Provinsi Jambi, sehingga akan meningkatkan kinerja keuangan daerah Provinsi Jambi. 2).Perlu dilakukan perencanaan yang tepat dan maksimalisasi anggaran belanja pada APBD yang berorientasi pada pembangunan dan kesejahteraan masyarakat. Sehingga peningkatan kinerja keuangan daerah secara riel juga berdampak terhadap kesejahteraan masyarakat.

\section{DAFTAR PUSTAKA}

Bacarreza,Gustavo Canavire., Vazquez, Jorge Martinez., \& Yedgenov, Bauyrzhan. (2019). Identifying and disentangling the impact of fiscal decentralization on economic growth, IDB working paper series $\mathrm{N}^{\mathrm{O}}$ IDB-WP-1037

Bartolini, David., Stossberg, Sibylle., \& Blöchliger, Hansjörg. (2016). Fiscal decentralisation and regional disparities, OECD Economics Department Working Papers No. 1330, https://dx.doi.org/10.1787/5jlpq7v3j237-en

Blöchliger,Hansjörg. (2018). Fiscal decentralisation and economic growth, https://www.researchgate.net/publication/326354962,doi:10.1787/97892643024 88-4-en

G.Chirwa,Themba., \& Odhiambo,Nicholas M. (2016). Macroeconomic determinants of economic growth: a review of international literature, South East European Journal of Economics and Business, 11 (2) 2016, 33-47 doi: 10.1515/jeb-20160009

Ganaie, Aadil Ahmad., Bhat, Sajad Ahmad., Kamaiah,Bandi, \& N. A. Khan. (2018). Fiscal decentralization and economic growth: evidence from indian state, South Asian Journal of Macroeconomics and Public Finance, 7(1) 83-108, doi: 10.1177/2277978718760071, http://journals.sagepub.com/home/smp

Kim, Junghun. (2019). Fiscal decentralisation and inclusive growth: An overview, OECD Fiscal Federalism Studies.

Korompot, Riska and Warongan,Jessy. (2017). Analysis of financial, performance in the government of North Sulawesi, Jurnal Accountability, 6(2), 2017, 9 - 19 